\title{
THE EFFECT OF DIFFERENT RECHARGE RATES ON THE RECHARGE CIRCLE IN THE RECHARGE WELLS
}

\author{
Ahmed Mohamed Metwally \\ Graduate Student, Civil Engineering Department, Al Azhar University, Cairo, Egypt
}

Anas Mohammed Almolla

Associate Professor, Civil Engineering Department, Al Azhar University, Cairo, Egypt

Rani Fouad Mohammed

Lecturer, Civil Engineering Department, Al Azhar University, Cairo, Egypt

Mostafa Ali Abdelaal

Professor, Civil Engineering Department, Al Azhar University, Cairo, Egypt

\begin{abstract}
In view of the importance of water in the whole world, especially in the areas that have begun to enter the water poverty space, attention must be paid to all sources of water, and on top of these sources is the water produced from the flood it is huge quantities of water that (mostly) are wasted and not directed to the best direction to preserve These quantities of water also protect it from pollutants, as well as protect lives and property from flood hazards.

It has been proven that artificial recharge projects are among the most important projects through which these large quantities of floodwater can be preserved. And we found that one of the best methods that lead to results that are closest to the truth and practical reality is to make a laboratory model that simulates all the elements that affect the operations of recharge groundwater through vertical perforated wells. The model was created for this purpose specifically.

All experiments were achieved in the Hydraulics Laboratory in the Faculty of Engineering of Al-Azhar University in Cairo, Egypt

After making the model, we calibrated it by making a numerical analysis model by the (GMS) program to facilitate the work of different scenarios and then extracting the results and recommendations that benefit all specialists in the field of groundwater recharge with anchored charging wells.
\end{abstract}

Keywords: Artificial recharge projects, Recharge wells, Flood water 
Cite this Article: Ahmed Mohamed Metwally, Anas Mohammed Almolla, Rani Fouad Mohammed, Mostafa Ali Abdelaal, The Effect of Different Recharge Rates on the Recharge Circle in the Recharge Wells, International Journal of Civil Engineering and Technology (IJCIET), 12(6), 2021, pp. 1-14. https://iaeme.com/Home/issue/IJCIET?Volume $=12 \&$ Issue $=6$

\section{INTRODUCTION}

The artificial recharge for recharge layer of soil by vertical wells is one of the important techniques that must be taken into consideration in the groundwater field and many of researcher has worked in this field that the groundwater flow model of a mountainous watershed in BM-60 watershed of Maharashtra state in India, has been developed with limited data to experimental trials of artificial recharge. USGS code MODFLOW is found suitable to generate the flow domain with more than one layer exposed to recharge from the injection wells. (Pradeep Kumar Majumdar et al. March 2009), artificial groundwater recharge will be beneficial in Saq Aquifer. Estimation of rechargeable water has been done which is very important before planning any groundwater recharge project. The maximum rate of recharge is estimated to be about 3,054 m3/day for the pond in "Alkhaleg". It is to be recharged round the year. One recharge well per pond is sufficient for this recharge rate in the study area. (Yousry M. Ghazaw \& Abdul R. Ghumman et al. 2013), conducted a study on Yogyakarta, a city on the island of Java, Indonesia, to increase the occurrence of floods in it and not to utilize the quantities of water in these floods. Artificial shipping wells were the most important means to preserve this amount of water and reduce the risk of floods and concluded that this city needs to develop scenarios for 519 recharge wells in order to cover amount of floods every year. And the consequences of this huge amount storage of water from the impact of the groundwater level and its effects on agriculture future, and explained the need for simulations and scenarios to reach the ideal states for charging rates that conserve water and control the water table. ( $\mathrm{S}$. Purwantara et al. 2019), (Tain-Shing et al. 1999), reported that the interest in restoring the habitat along riparian corridors has necessitated quantifying the interaction between the surface and groundwater conditions, particularly in the lower flow conditions, understanding the transient nature of the river seepage losses and groundwater accretions / depletions is critical in assessing the surface and subsurface riparian environment. They described the application of MODFLOW for simulating the effects of changes in surface water flow on groundwater elevations. They reported that the calibration is initiated with the available data, but the rigorous calibration demands for large data. (Mostafa Ali Abdelaal et al. 2020), record that when estimating the improvement in the distance between wells, it is possible to achieve the maximum benefit from the well capacity of the well. and recommended to calibrate the screen perforation before operating it; to make sure that it will give the required rate., because the type, thickness, material, and the quality of perforation have a significant impact on recharge rates.

\section{THEORETICAL APPROACH}

The relationships between all parameters, affecting the recharge well, were comprehended.

Applying Buckingham $\pi$-theorem and taking $H, \rho$ and gas the repeating variables, we can see that the number of variables affecting the phenomenon (n) equals 22 , and the number of fundamental dimensions involved (m) equals 3 which are M,L and T ,so the number of nondimensional parameter (n-m) will be equal to 19 are as following equation (2-1) and (Table 1) explain the dimensional parameter . 


$$
\frac{q}{\sqrt{g} * h^{5 / 2}}=f\left(\frac{B_{1}}{B_{2}}, \frac{h_{1}}{H_{2}}, \frac{h_{2}}{h_{w}}, \frac{h_{t}}{H}, \frac{X}{Y}, \frac{\mu_{1}}{\delta \sqrt{g} * H^{3 / 2}}, \frac{k_{1 x}}{k_{2 x}}, \frac{k_{1 y}}{k_{2 y}}, \frac{k_{1 z}}{k_{2 z}}, \frac{L_{s}}{H}, \frac{D}{d}\right)
$$

Table 1 Definition of dimensional parameter

\begin{tabular}{|c|l|}
\hline Symbol & \\
\hline B1 $=$ & Length of sand tank model. \\
\hline B2 $=$ & Width of sand tank model. \\
\hline H $=$ & Height of water column. \\
\hline h1 $=$ & Height of recharge layer. \\
\hline h2 $=$ & Height of above layer. \\
\hline $\mathrm{X}=$ & Distance from original point @ X axis. \\
\hline $\mathrm{Q}=$ & Discharge of well. \\
\hline $\mathrm{G}=$ & Gravitational acceleration. \\
\hline$\rho=$ & Mass density of fluid. \\
\hline$\mu=$ & Dynamic viscosity. \\
\hline $\mathrm{K} 1 \mathrm{x}=$ & Hydraulic conductivity from the soil of recharge layer @ X direction. \\
\hline $\mathrm{K} 1 \mathrm{y}=$ & Hydraulic conductivity from the soil of recharge layer @ Y direction. \\
\hline $\mathrm{K} 1 \mathrm{z}=$ & Hydraulic conductivity from the soil of recharge layer @ Z direction. \\
\hline Ls $=$ & Length of screen. \\
\hline $\mathrm{D}=$ & The distance from the well to the last point of impact. \\
\hline $\mathrm{B} 1=$ & Length of sand tank model. \\
\hline $\mathrm{B} 2=$ & Width of sand tank model. \\
\hline $\mathrm{H}=$ & Height of water column. \\
\hline $\mathrm{h} 1=$ & Height of recharge layer. \\
\hline $\mathrm{h} 2=$ & Height of above layer. \\
\hline $\mathrm{X}=$ & Distance from original point @ X axis. \\
\hline $\mathrm{Q}=$ & Discharge of well. \\
\hline $\mathrm{G}=$ & Gravitational acceleration. \\
\hline$\rho=$ & Mass density of fluid. \\
\hline$\mu=$ & Dynamic viscosity. \\
\hline $\mathrm{K} 1 \mathrm{x}=$ & Hydraulic conductivity from the soil of recharge layer @ X direction. \\
\hline $\mathrm{K} 1 \mathrm{y}=$ & Hydraulic conductivity from the soil of recharge layer @ Y direction. \\
\hline $\mathrm{K} 1 \mathrm{z}=$ & Hydraulic conductivity from the soil of recharge layer @ Z direction. \\
\hline Ls $=$ & Length of screen. \\
\hline $\mathrm{d}=$ & Diameter of well screen. \\
\hline & \\
\hline & \\
\hline & \\
\hline & $=$ \\
\hline &
\end{tabular}

\section{EXPERIMENTAL WORK}

An experimental work program in laboratory was designed based on several steps, all these steps will be explained as follows:

\subsection{Sand Tank Model}

Sand tank model (photo 1) is the element through which the soil is represented, and the dimensions are as follows: Length $=120 \mathrm{~cm}$. Width $=120 \mathrm{~cm}$ and Height $=80 \mathrm{~cm}$. 
The Effect of Different Recharge Rates on the Recharge Circle in the Recharge Wells

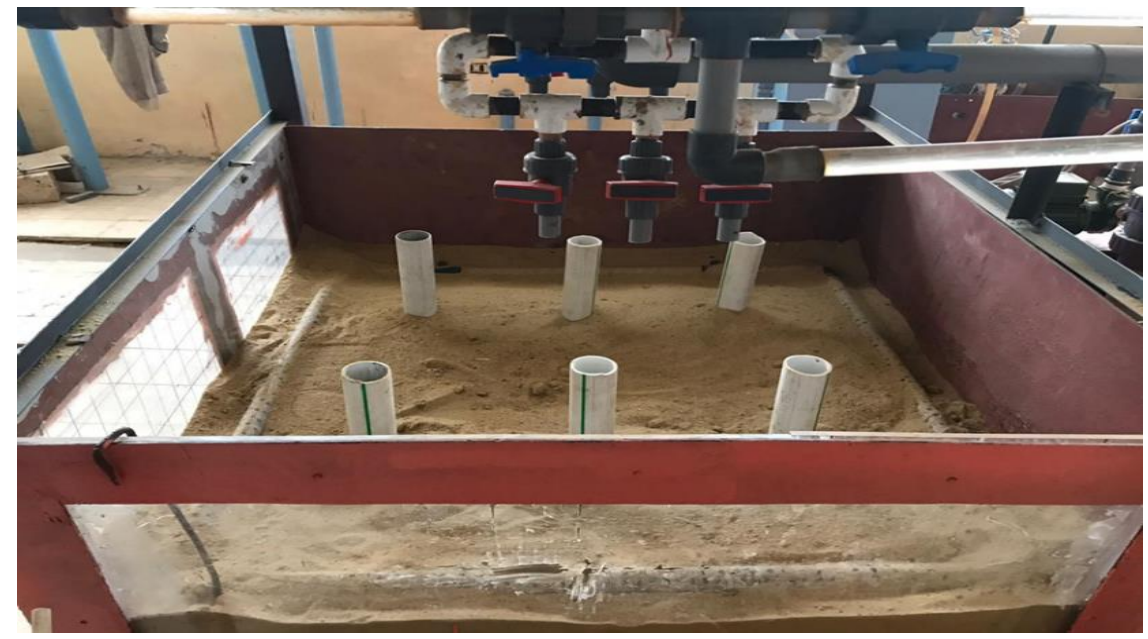

Photo 1 Sand tank model

\subsection{Recharge Wells}

A well was made to simulate the recharge well and make the necessary perforations for it (photo 2). These data can be summarized as follows (Table 2).
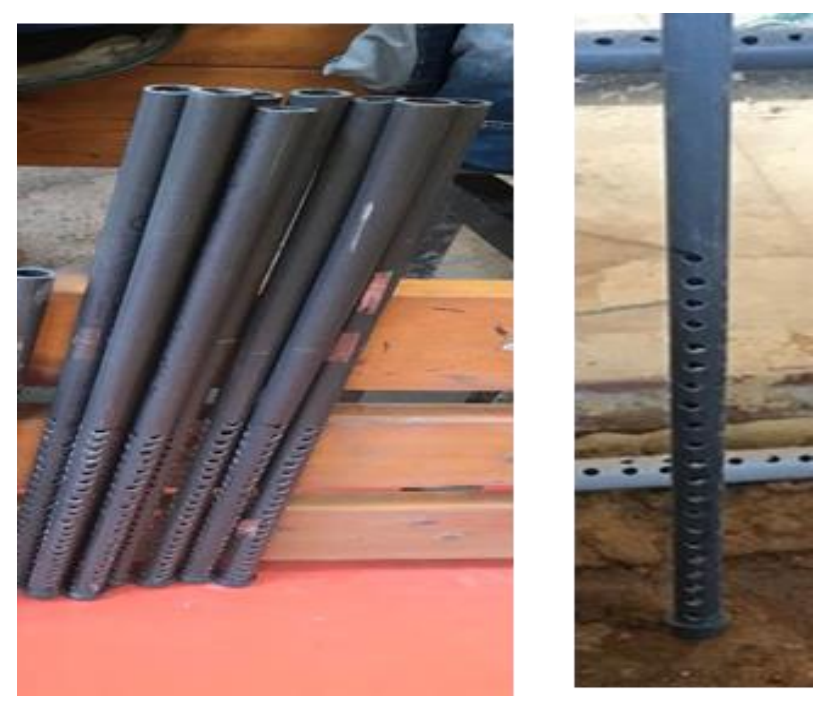

Photo 2 Recharge Wells

Table 2 Data of recharge wells

\begin{tabular}{|l|l|c|c|}
\hline \multicolumn{1}{|c|}{ Symbol } & \multicolumn{1}{c|}{ Definition } & Dimension & Units \\
\hline Ls & Length of screen & 40 & $\mathrm{~cm}$ \\
\hline Dout & Outer diameter of well screen. & 2.1 & $\mathrm{~cm}$ \\
\hline Din & Inner diameter of well screen. & 1.6 & $\mathrm{~cm}$ \\
\hline Davr well & average diameter & 1.85 & $\mathrm{~cm}$ \\
\hline $\mathrm{t} \mathrm{s}$ & thickness of screen & 0.25 & $\mathrm{~cm}$ \\
\hline $\mathrm{d}$ & Diameter of opening screen. & 0.8 & $\mathrm{~cm}$ \\
\hline $\mathrm{n} 1$ & Number of opening & 84 & $\mathrm{no}$ \\
\hline ao & Area of one open & 0.5024 & $\mathrm{~cm} 2$ \\
\hline Ao & Total area of opening & 232.36 & $\mathrm{~cm} 2$ \\
\hline Perf.r & Percentage of perforation & $18.16 \%$ & $\%$ \\
\hline
\end{tabular}


The wells were installed in the places shown in the following (Figure 1) and (Photo 3) and all dimensions are in centimeters,

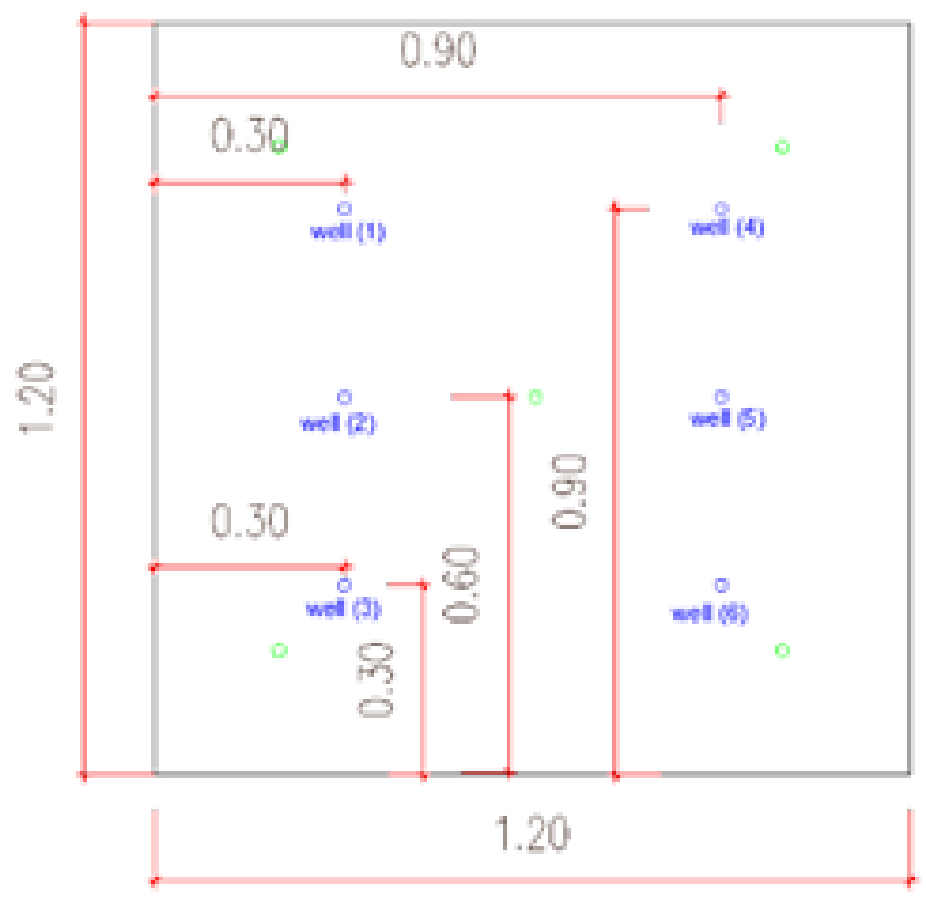

Figure 1 Coordinates of wells

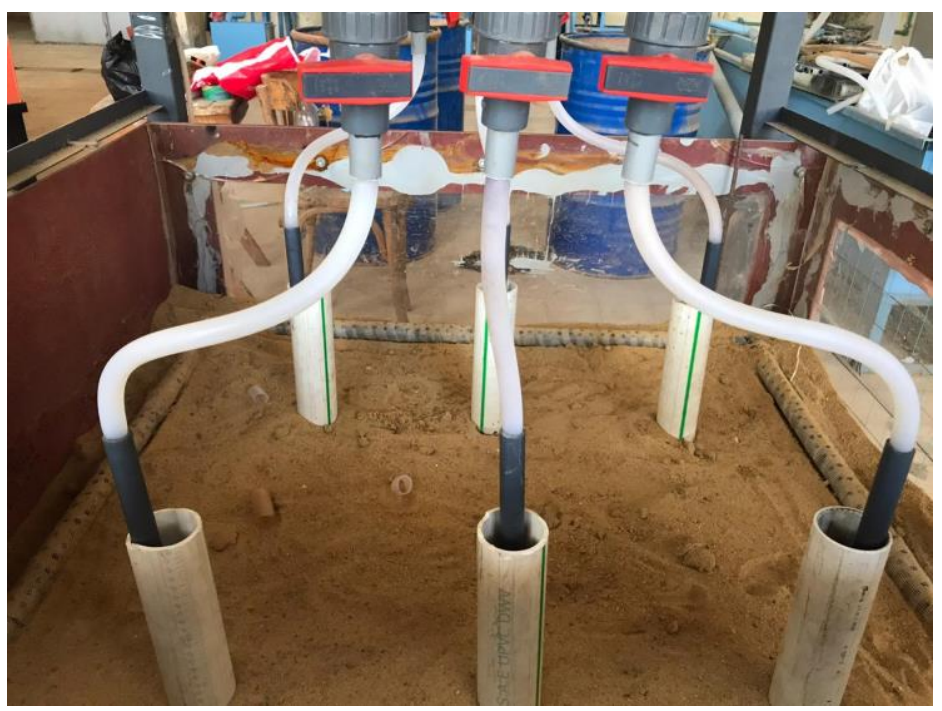

Photo 3 coordinates of wells in sand tank model

\subsection{Controlling the water level of wells in the recharge layer}

A tool has been developed to control the height of the recharge well inside the recharge layer and to ensure that water does not leak below it, which allows us to measure recharge rates at different heights within the shipping layer. (Photo 4) 

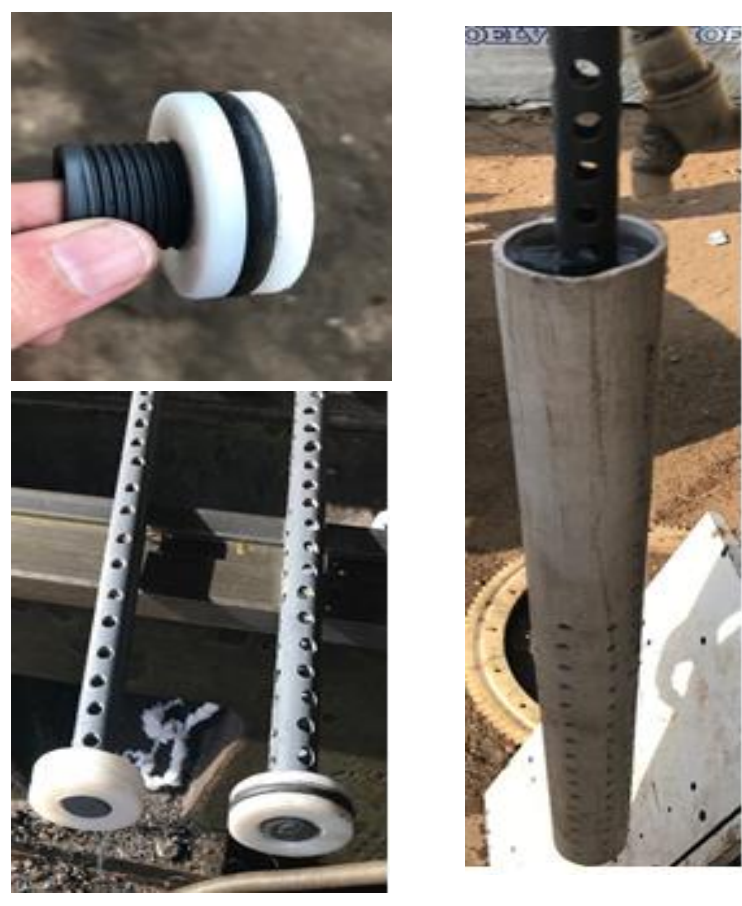

Photo 4. A tool to control the water level inside the soil

\subsection{Reservoir \& Pumping}

Establishing a tank to supply the required water to the experiment, and it was connected to a pump of suitable power to pump water throughout the experiment (Photo 5) it is dimensions as following:

Length $=120 \mathrm{~cm}$, Width $=30 \mathrm{~cm}$ and, Height $=60 \mathrm{~cm}$

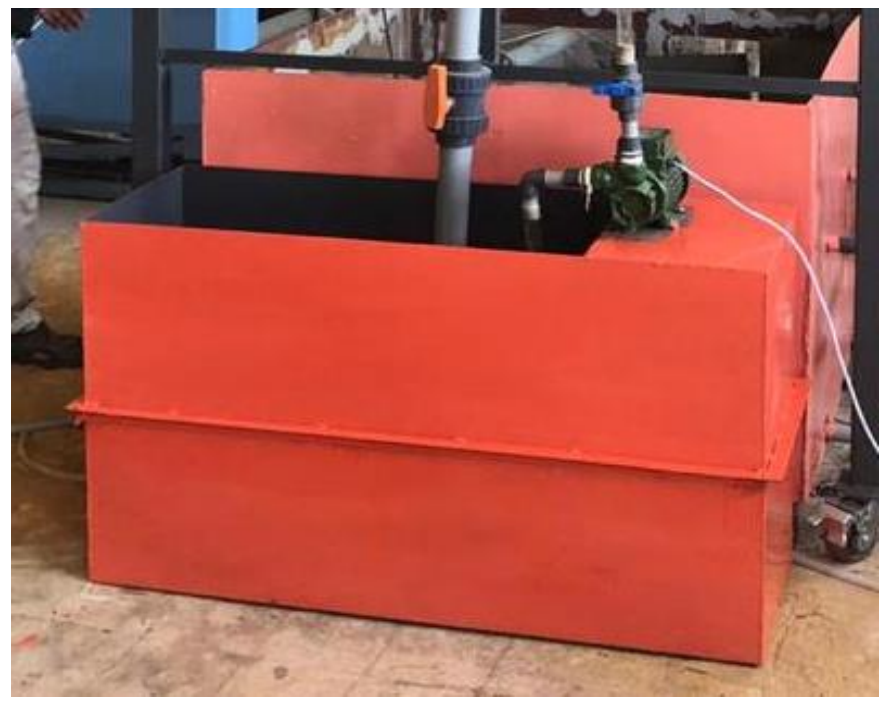

Photo 5 A Reservoir \& pumping location

\subsection{Control the head of water}

An upper tank is equipped to which the water is raised by the pump, and it is equipped with four inlets to maintain the regularity of the shape and regularity of the incoming water. (Photo 6) 
A weir has also been provided in the middle to precisely control the water level inside the upper tank, to ensure that the water height above the surface of all wells is equal.

This weir can be controlled up and down according to different experiment requirements

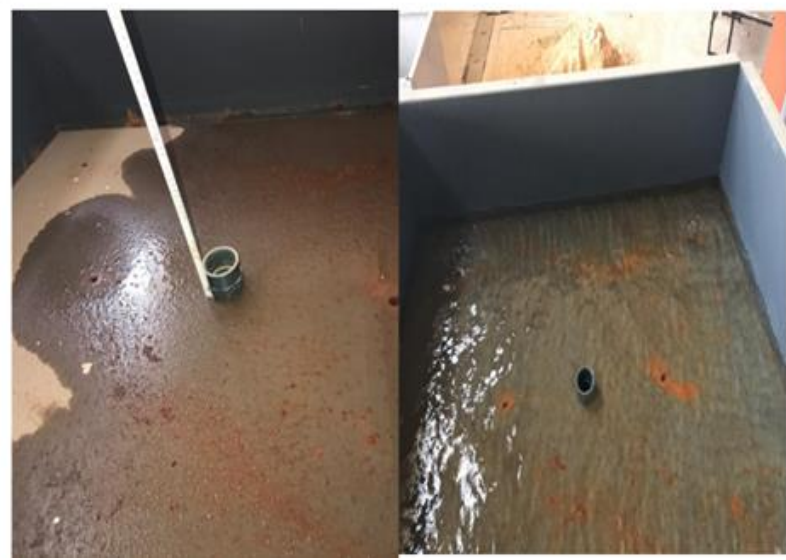

Photo 6 Inlet of water and weir

\subsection{Observation Wells}

Five observation wells and they are about 5 piezometers (Figure 8) are equipped to find out the water level inside the recharge soil layer their coordinates Were as Follows:

Observation well (no. 1)=20 cm @ axis X\&20 cm @ axis Y.

Observation well (no. 2) $=20 \mathrm{~cm} @$ axis X\&100 cm @ axis Y.

Observation well (no. 3)=100 cm @ axis X\&100 cm @ axis Y.

Observation well (no. 4) =100 cm @ axis X\&20 cm @ axis Y.

Observation well (no. A) $=60 \mathrm{~cm} @$ axis X \& $60 \mathrm{~cm} @$ axis Y.

All coordinates start from the Original point $(0,0)$ and the following (Figure 2) dimensions are in centimeters

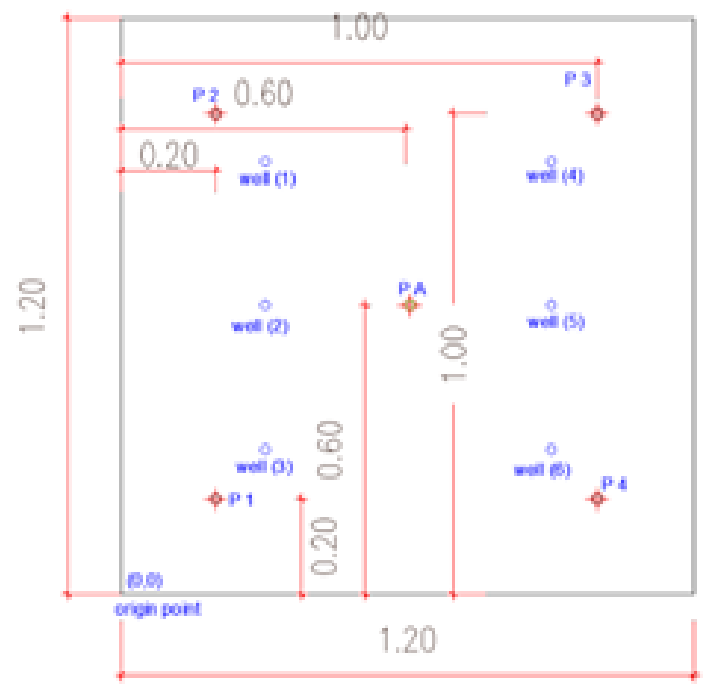

Figure 2. Coordinates of observation wells

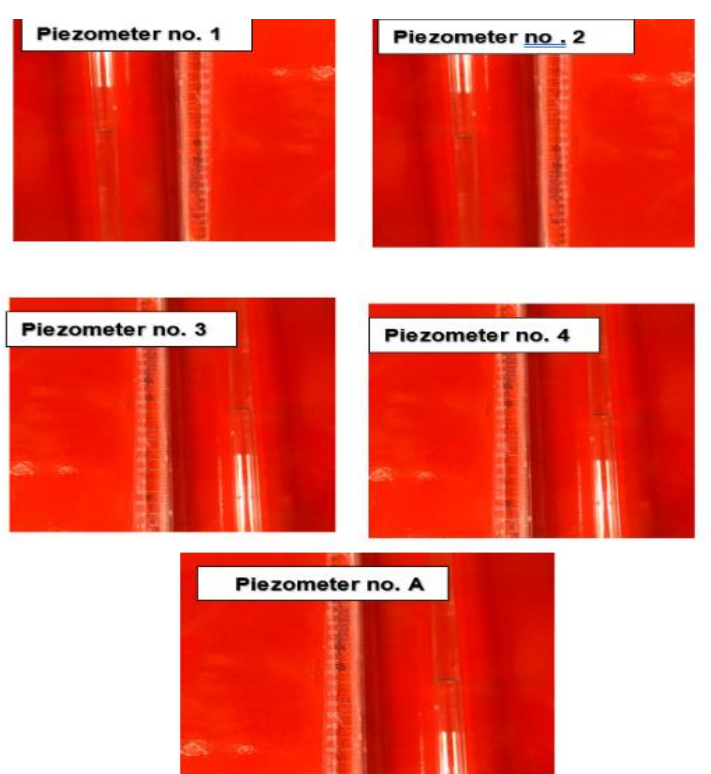

Photo 7. Observation piezometers 


\subsection{Methodology of Water Movement}

The pump raises the water stored in the lower tank to four entry points connected to the upper tank. It is important to ensure that all the valves on the four points give the same flow rate, and the weir is adjusted to the required water level and the weir rotates the excess water to return to the lower tank for reuse once Another experiment, so that the water level over all wells becomes equal, giving equal charging rates for all wells. (Photo 8)

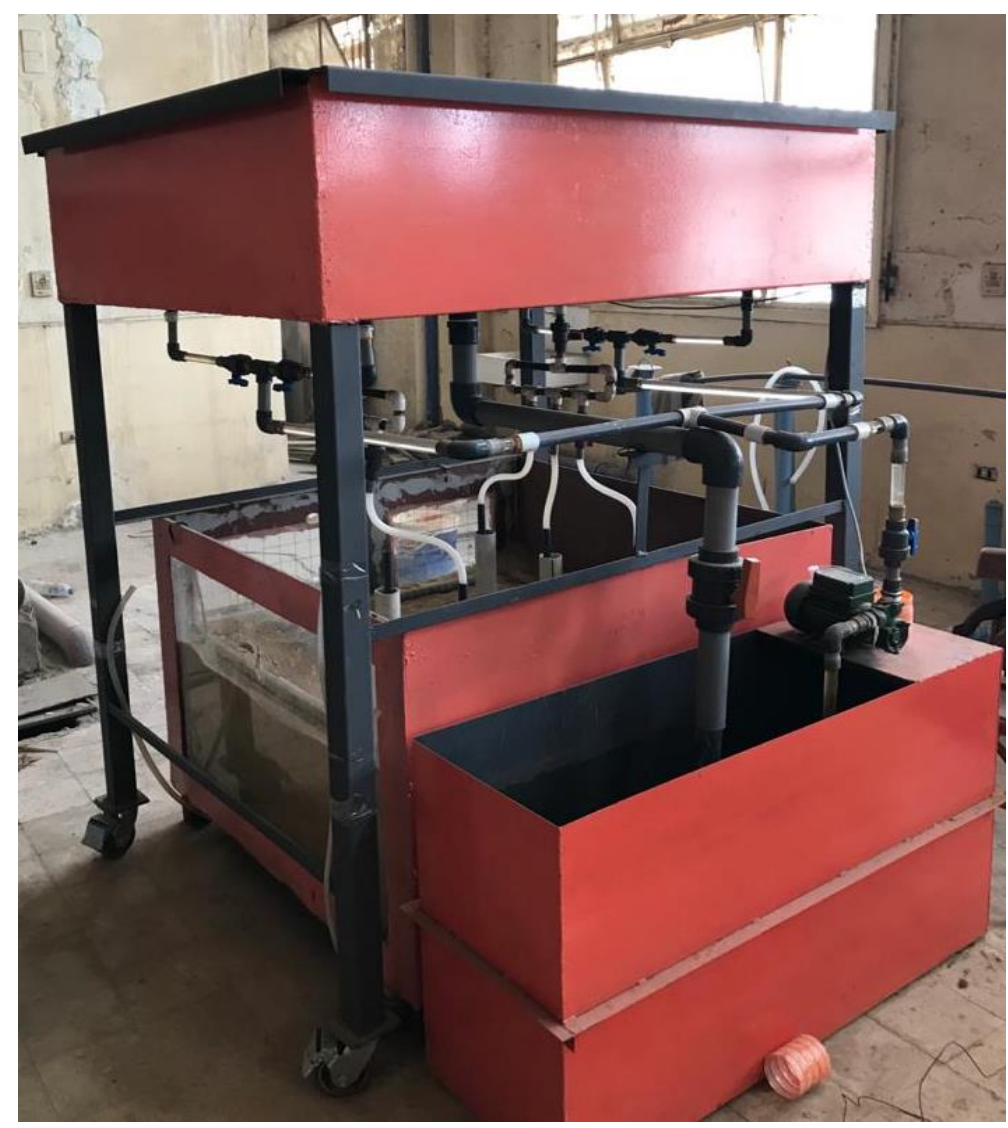

Photo 8 3D view for all components of model

\section{NUMERICAL MODELING}

Groundwater flow and contaminant transport models are being extensively used in the studies related to groundwater systems. Groundwater flow models are used to calculate the rate and direction of movement of groundwater through aquifers and confining units in the subsurface.

\subsection{Calibration of Model}

Calibrators were made using the results of recharge rates from the laboratory experiment to reach the hydraulic conductivity that is consistent with the GMS program, and the calibration steps are as follows:

Attempts began from 1 meter per day for hydraulic conductivity

Until we get to the nearest value, it expresses the value of hydraulic conductivity, which is 47 meter per day

The following are some of the attempts: (Figure 3) 

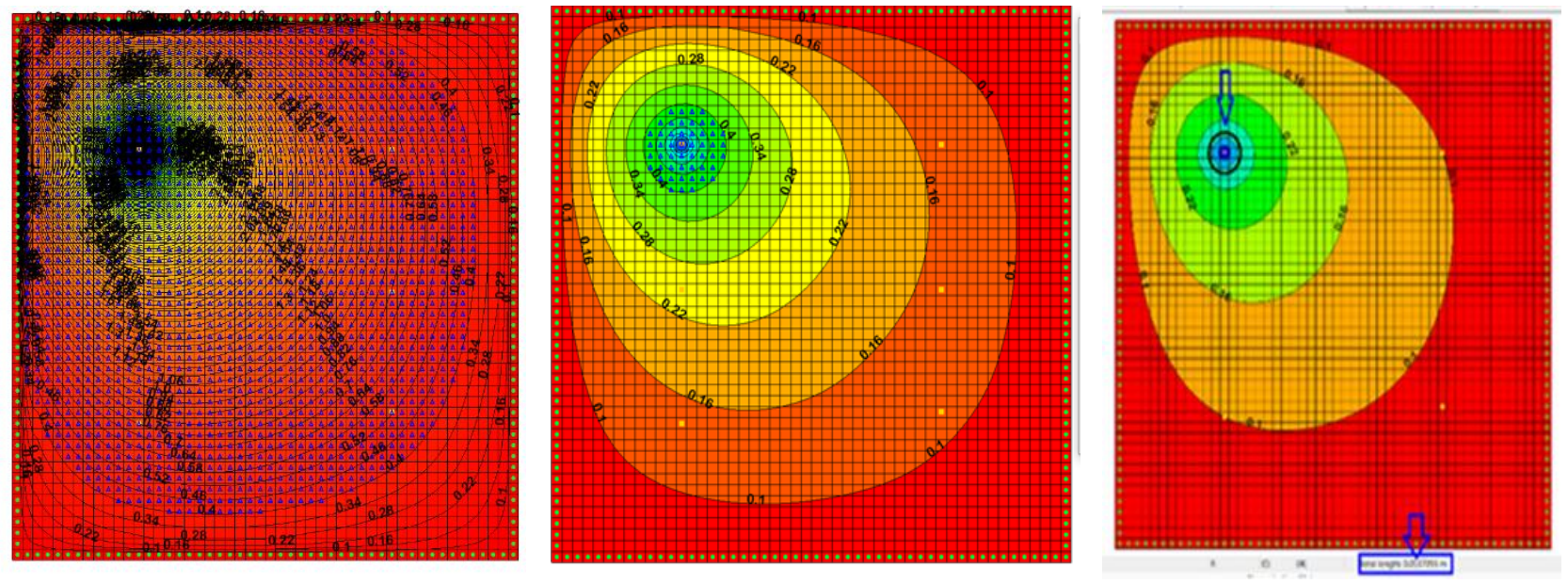

Figure 3 Clarifies the titration stages starting from 1,20 and 47 meter per day for hydraulic conductivity

\subsection{Verification of Model}

By taking the readings of water height in the pressure gauge for all monitoring wells over the time from the laboratory experiment and calibrating the same site with the observation wells in the numerical model, the compatibility of the numerical program with the laboratory model must be verified. We arrived at an accuracy result ranging from 90 percent to 95 percent, and (Figure 4\&5)illustrates this:

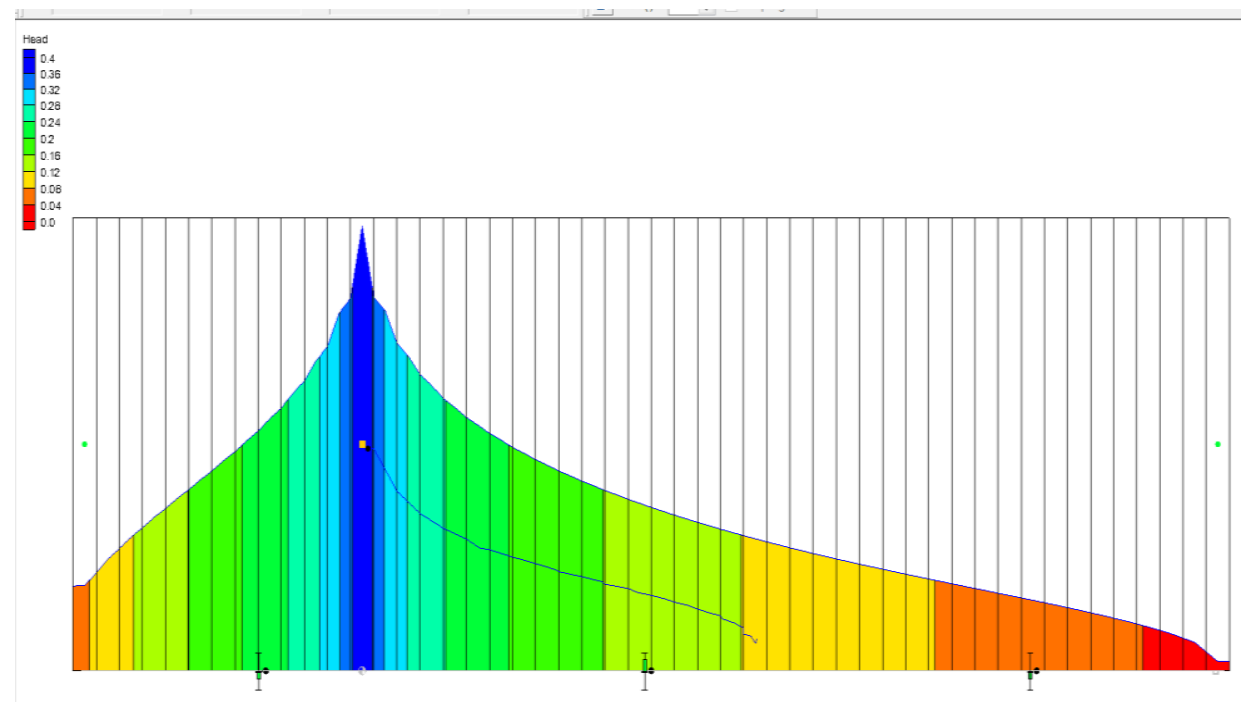

Figure 4 Showing the Observation Well with In Target Value X direction 


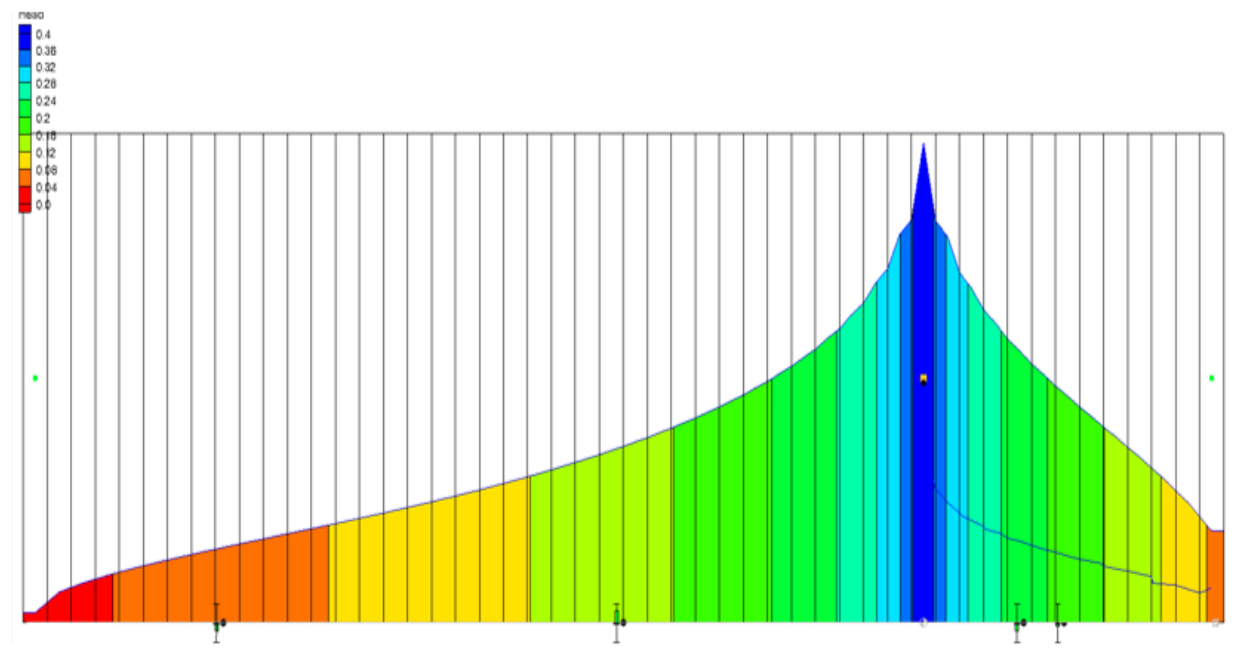

Figure 5 Showing the Observation Well with In Target Value Y direction

\section{RESULTS AND DISCUSSION}

After reviewing the literature, adopting the theoretical approach, carrying out experiments, and conducting measurements so that the readings are recorded with the observations being documented to take pictures, by analyzing all the results and drawing them on charts, and including them in tables and presenting them, the laboratory results we have come to can be summarized as follows:

When (well No. 1) was operating at a recharge rate of 7.27 cubic meters per day, and taking measurements of the height of the water inside the monitoring wells, which are known distances from well No. 1, and drawing the curve between the recharge rate and the heights of water inside the monitoring wells, (Curve 1) The maximum distance that the well influence circle can reach under this recharge rate in this soil is $172.91 \mathrm{~cm}$.

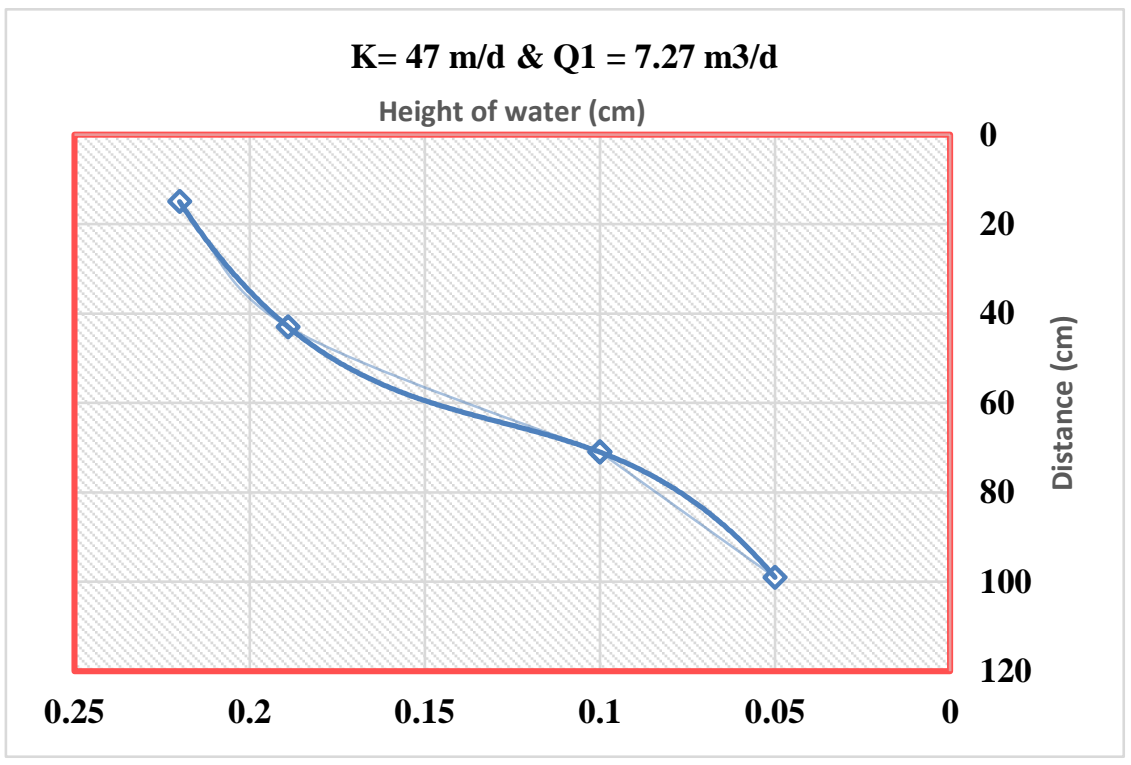

Curve 1 Distance of influence circle \& Height of Water in monitoring wells With Q1

After that, the recharge rate was reduced to reach 6.11 cubic meter per day and operated Well No. 1 and taking measurements of the height of the water inside the monitoring wells, which are known distances from well No. 1, and drawing the curve between the recharge rate 
and the heights of water inside the monitoring wells, (Curve 2)The maximum distance that the well influence circle can reach under this recharge rate in this soil is $165.03 \mathrm{~cm}$.

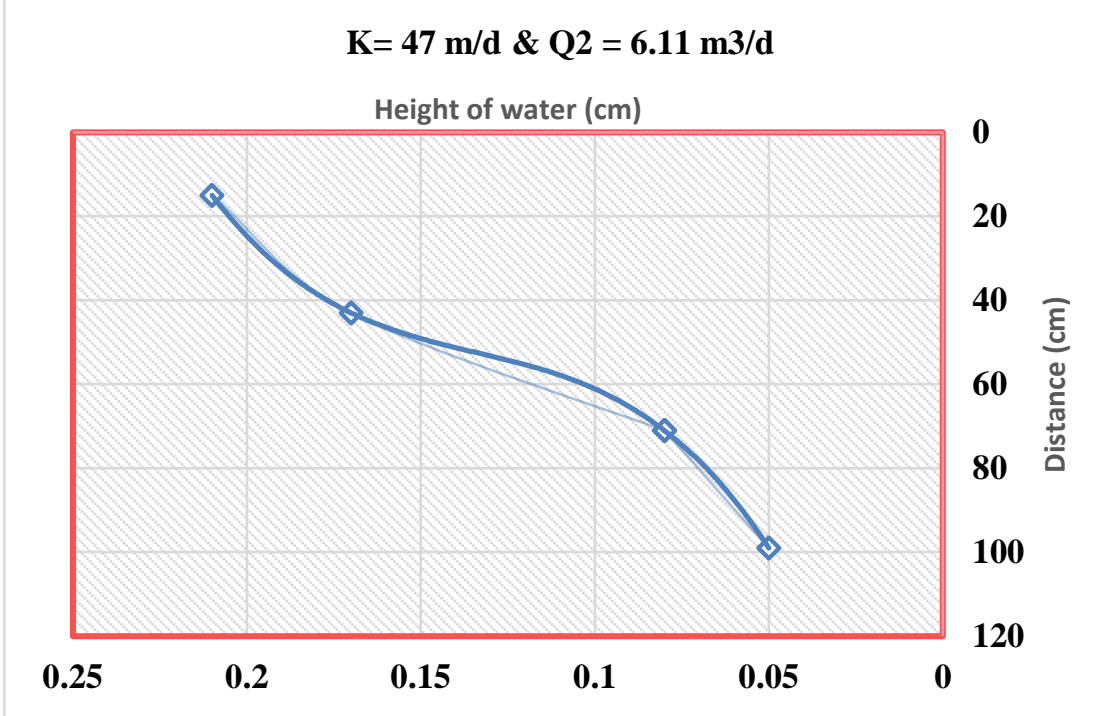

Curve 2 Distance of influence circle \& Height of Water in monitoring wells With Q2

In the third operating case, the feed rate was reduced to 5.11 cubic meters per day, and the same well No. 1 was operated and taking measurements of the height of the water inside the monitoring wells, which are known distances from well No. 1, and drawing the curve between the recharge rate and the heights of water inside the monitoring wells, curve 3 . The maximum distance that the well influence circle can reach under this recharge rate in this soil is 133.94 $\mathrm{cm}$.

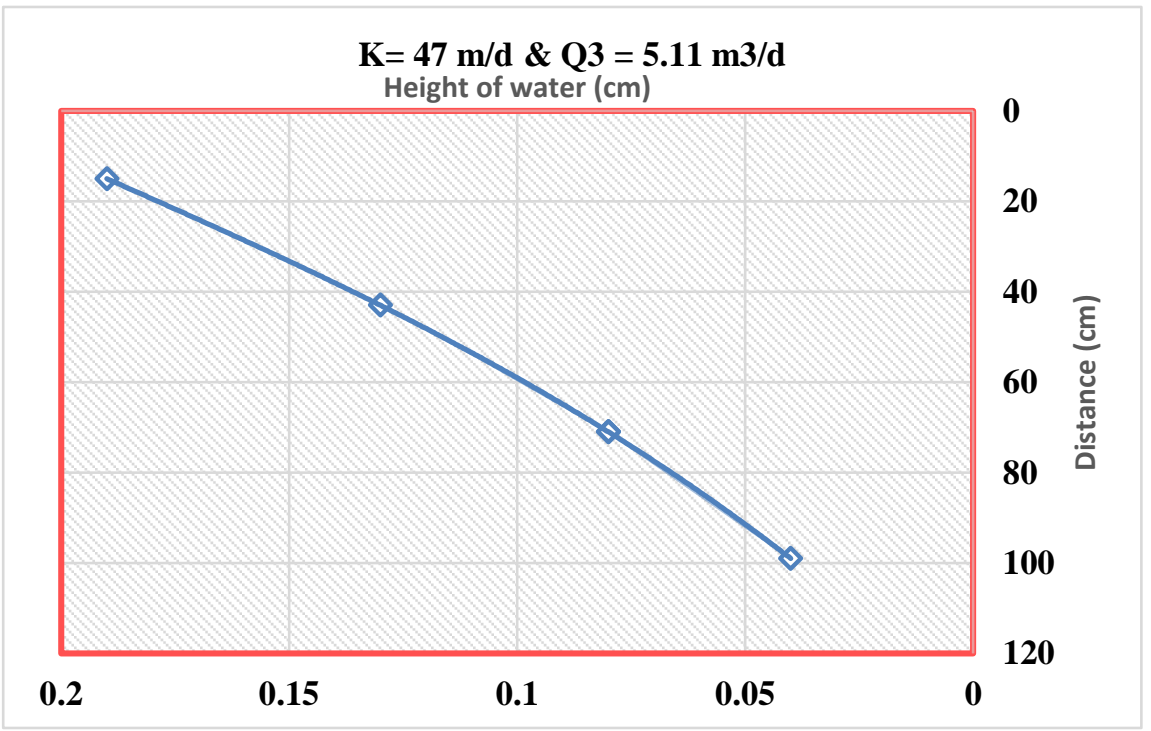

Curve 3 Distance of influence circle \& Height of Water in monitoring wells With Q3

In the last case, in which the recharge rate was 3.57 cubic meters per day, and taking the readings of the monitoring wells, and drawing the curve between the recharge rate and the heights of water inside the monitoring wells, (Curve 4) The maximum distance that the well influence circle can reach under this recharge rate in this soil is $124.45 \mathrm{~cm}$. 


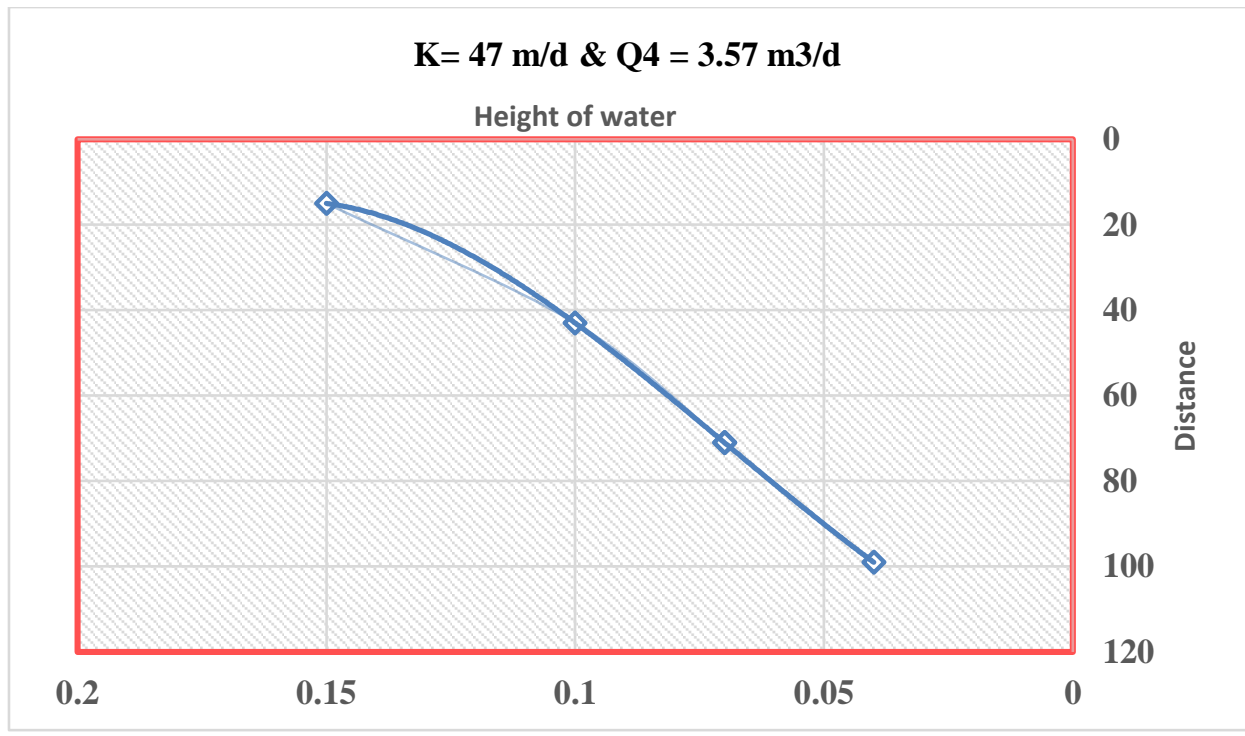

Curve 4 Distance of influence circle \& Height of Water in monitoring wells With Q4

To benefit from all previous laboratory experiences and to apply these experiences on a large scale in artificial recharge projects, Then the theoretical approach "dimensional analysis" was adopted to relate the combined variables. And the conclusion of the next (Curve 5)

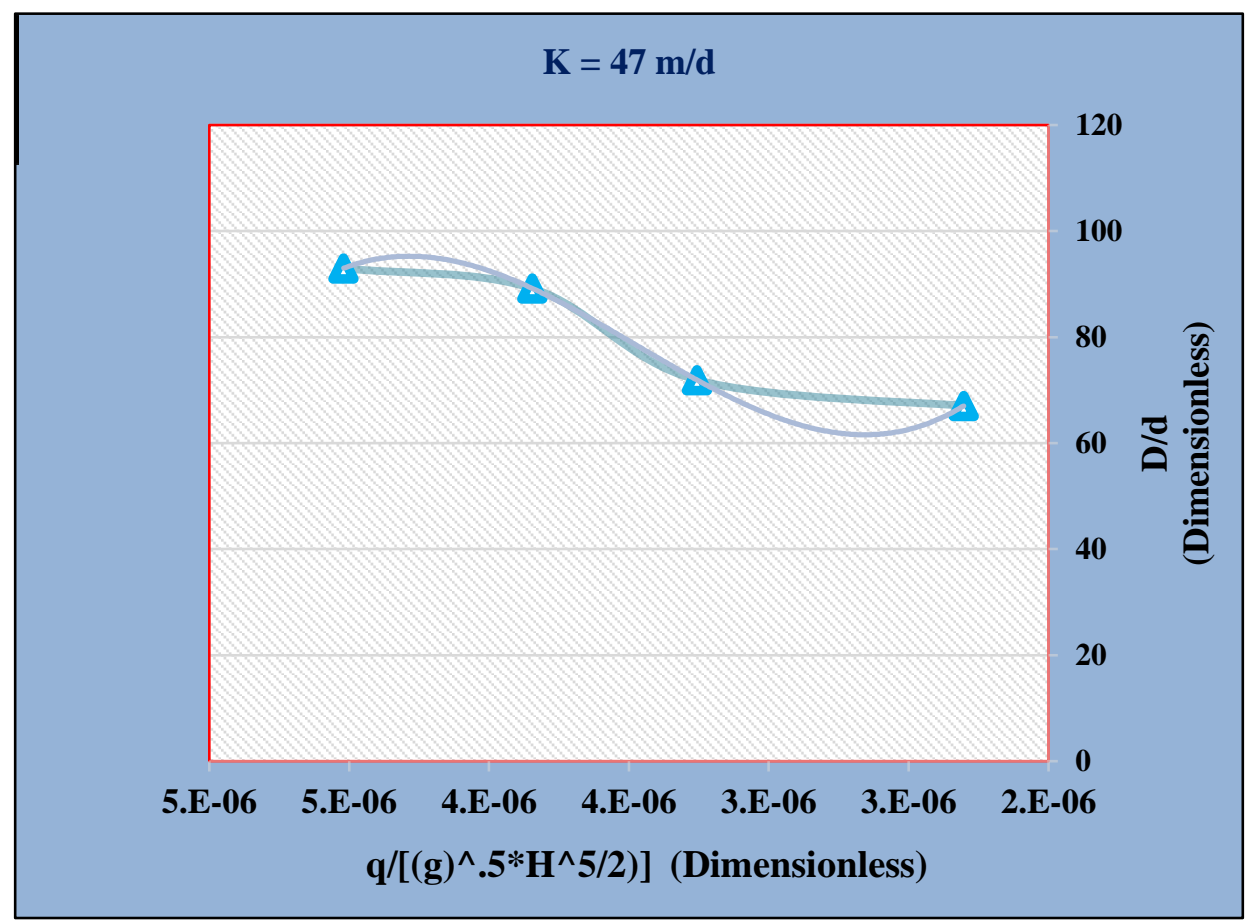

Curve 5 Design chart

\section{CONCLUSION}

In the context of understanding the behavior of recharge wells for artificial recharge projects due to their great importance in preserving and storing floodwater, this research began with the aim of finding the effect of different flows on the cycle of influence of the recharge well. An in vitro model simulating artificial recharge was chosen.

Primarily, the literature was reviewed and understood in the field of artificial feeding. 
Then the theoretical approach "dimensional analysis" was adopted to relate the combined variables. The conclusions can be summarized as follows:

- The laboratory model used can be used to simulate artificial recharge projects and evaluate the performance of different recharge rates at a laboratory with small dimensions and costs before starting the construction work in the field, which often has a high cost.

-The sensitivity of the recharge rates is very high due to the height of the water level above the surface of the recharge well, so the recharge rates can be controlled by controlling the height of the storage lake over the well.

-The well impact circle is one of the important factors that must be carefully studied, which leads to determining the optimal number of wells used for each different type of soil.

-Design Curve No. 5 can be used to determine the diameter of the recharge well and the influence circle with different flows of the soil.

\section{ACKNOWLEDGEMENTS}

I would like to thank my thesis advisor Prof. Dr. Anas El-Molla, of the Faculty of Engineering at Al-Azhar University. The door to Prof. A. El-Molla office was always open whenever I ran into a trouble spot or had a question about my research or writing. He consistently allowed this paper to be my own work but steered me in the right the direction whenever he thought I needed it.

My deepest gratitude to Prof. Dr. Mostafa Ali, for proposing the present point of research, planning the work, valuable advices, and reviewing the manuscript.

\section{REFERENCES}

[1] Pradeep Kumar Majumdar 2009 C.U. Shah University; "Artificial Recharge in Multi aquifers of a Mountainous Watershed "

[2] Yousry M. Ghazaw \& Abdul R. Ghumman / Published online: 13 September 2013 ( ) King Fahd University of Petroleum and Minerals 2013 "Investigations of Impact of Recharge Wells on Groundwater in Buraydah by Numerical Modeling "

[3] S. Purwantara ;2019 "Optimization of Recharge Well Functions In The Campus Complex of Uny Yogyakarta"

[4] Tain-Shing Ma, (1999),"MODFLOW simulation of transient surface water/Groundwater interactions in a shallow Riparian zone using HEC-2-based water surface profiles", USBR surfacegroundwater paper, Contract No: 99-CS-20-2084.

[5] Mostafa Ali Abdelaal 2020“. The effect of well's spacing on the recharge rates " life science Journal " 2020;17(4)

[6] Arif Ismail;2018 "Determining the number of Recharge Wells Needs in Universitas Pendidikan Indonesia, Bandung"

[7] Edy Susilo;2018 "Field performance of shallow recharge well "https://doi.org/10.1051/matecconf/201819505006

[8] Fiaz Hussain;2019 "Rainwater Harvesting Potential and Utilization for Artificial Recharge of Groundwater Using Recharge Wells"

[9] James W.M. and Charles R.F. ,(1981), “Ground Water Modelling: An overview”, Vol.19, No.2, pp. 108-115.

[10] Larner D.N. ,(1997), "Groundwater recharge. In: Saether OM, de Caritat P (eds) Geochemical processes, weathering and groundwater recharge in catchments", AA Balkema, Rottrdam, pp. $109-150$. 
The Effect of Different Recharge Rates on the Recharge Circle in the Recharge Wells

[11] Martin Preene,(2016), "Groundwater control”Preene Groundwater Consulting, , discusses the importance of groundwater control and dewatering for underground works, and gives guidance on good practice.

[12] Mostafa Ali Abdelaal 2020“. The effect of well's spacing on the recharge rates " life science Journal " 2020;17(4)

[13] O'Hare1986, M.P., Fairchild, D.M., Hajali, P.A., Canter, L.W. 1986. "Artificial Recharge of Groundwater". Proceedings of the Second International Symposium on Artificial Recharge of Groundwater.

[14] Roger A. Luyun ;2019 "Laboratory-Scale Investigation of Recharge Wells for Groundwater Storage "Recharge well for groundwater storage-Luyun et al-PJABE 2019 Vol 15 No 1

[15] Singh D.K., (2002), "Groundwater Development, Use and Management in India", National Training Program on Watershed Based Water Management for Sustainable Development, October 3-1 